\title{
PENGARUH PEMBERIAN ABU JANJANG KELAPA SAWIT DAN PUPUK ORGANIK JAGO TANI TEHADAP PERTUMBUHAN VEGETATIF TANAMAN KARET
}

\author{
Amir Mahmud ${ }^{\left.1^{*}\right)}$, Samsinar ${ }^{2 *}$ \\ ${ }^{1 *}$ Email: amir.mahmud@um-tapsel.ac.id \\ ${ }^{1,2 *}$ Fakultas Pertanian Universitas Muhammadiyah Tapanuli, Sumatera Utara
}

\begin{abstract}
ABSTRAK
Penelitian ini bertujuan untuk mengetahui pengaruh Abu Janjang Kelapa Sawit dan Pupuk Organik Jago Tani terhadap Pertumbuhan Vegetatif Karet Okulasi (havea brassiliensis). Penelitian ini dilaksanakan di lokasi Kelurahan Batang Ayuni Julu, Kecamatan Padangsidimpuan Utara, Kabupaten Tapanuli Selatan, Ketinggian tempat 500 meter dari permukaan laut. Waktu penelitian dilaksanakan bulan Februari 2017 dan Penelitian selesai pada bulan Juli 2017. Penelitian ini dilakukan dengan menggunakan rancangan Acak Kelompok (RAK) dalam bentuk faktorial, yaitu 2 faktor , faktor pemberian Abu Janjang Kelapa Sawit disimbolkan (A), dengan 4 level yaitu $A_{0}, A_{1}, A_{2}$, dan $A_{3}$ dan Pupuk Organik Jago Tani disimbolkan (J), dengan 4 level yaitu $\mathrm{J}_{\mathbf{0}}, \mathrm{J}_{\mathbf{1}}, \mathrm{J}_{\mathbf{2}}$, dan $\mathrm{J}_{\mathbf{3}}$. Dari hasil analisis secara statistik diperoleh bahwa perlakuan Abu Janjang Kelapa Sawit memberikan respon yang nyata pada pengamatan tinggi tanaman umur 4 mst, 8 mst, dan 12 mst. Sedangkan respon yang tidak nyata dijumpai pada pengamatan diameter batang umur $4 \mathrm{mst}, 8 \mathrm{mst}$, dan $12 \mathrm{mst}$, pengamatan jumlah tangkai umur $4 \mathrm{mst}, 8 \mathrm{mst}$, dan $12 \mathrm{mst}$, pengamatan luas daun pada umur 6 mst, dan 12 mst. Dari hasil analisis statistik diperoleh bahwa pemberian Pupuk Organik Jago Tani memberikan respon yang tidak nyata pada pengamatan tinggi tanaman 4 mst, 8 mst, dan 12 mst, pengamatan diameter batang umur 4 mst, 8 mst, dan 12 mst, pengamatan jumlah tangkai umur 4 mst, 8 mst, dan 12 mst, pengamatan luas daun pada umur 6 mst, dan 12 mst. Penelitian ini menggunakan Abu Janjang Kelapa Sawit pada pengamatan nilai tertinggi pada perlakuan A2 ( 50 gr). Pada pengamatan Jago Tani nilai tertinggi pada perlakuan J2 (4 cc/liter air).
\end{abstract}

Kata Kunci : Abu janjang kelapa sawit, pupuk organik Jago Tani, 


\section{PENDAHULUAN}

Tanaman karet termasuk famili Euphorbiaceae atau tanaman getah-gatahan. Dinamakan demikian karena golongan famili ini mempunyai jaringan tanaman yang banyak mengandung getah (lateks) dan getah tersebut mengalir keluar apabila jaringan tanaman terlukai. Mengingat manfaat dan kegunaannya, tanaman ini digolongkan ke dalam tanaman industri (Sianturi, 2007).

Sesuai dengan nama latin yang disandangnya tanaman karet (Hevea brassiliensis) berasal dari Brazil. Tanaman ini merupakan sumber utama bahan karet alam dunia. Padahal jauh sebelum tanaman karet dibudidayakan, penduduk asli di berbagai tempat seperti Amerika Selatan, Afrika, dan Asia menggunakan pohon-pohon lain yang juga menghasilkan getah. Sebagai penghasil lateks, tanaman karet dapat dikatakan merupakan satu-satunya tanaman yang dikebunkan secara besar-besaran (Setiawan dan Agus Andoko, 2006).

Dewasa ini, luas areal tanaman karet mencapai 3,04 juta hektar, dimana 83,4 \% (92,54 juta hektar) adalah karet rakyat. Oleh karena itu, selain sebagai sumber devisa, karet rakyat juga memiliki arti sosial yang sangat penting karena mendukung lebih dari 10 juta jiwa keluarga petani yang mengusahakan komoditas ini. Walaupun demikian, produktivitas karet rakyat saat ini masih tergolong rendah, yakni hanya sekitar 300-400 kg karet kering per hektar per tahun. Pemerintah telah memberi perhatian khusus pada sektor tanaman perkebunan untuk menjadi sumber devisa negara yang akan datang, terutama dalam masa yang dekat ini (Tim Penulis, 2012).

Indonesia pernah menjadi produsen karet alam nomor satu di dunia. Tanaman karet diusahakan dimana-mana. Perkebunan besar milik pemerintah berdampingan dengan perkebunan besar swasta dan perkebunan rakyat memperkuat posisi Indonesia sebagai negara produsen karet utama, mengatakan bahwa pada umumnya tanaman karet rakyat belum dikelola secara baik, sehingga produktivitas masih jauh dari yang diharapkan, karena bibit yang digunakan masih bibit sembarangan (Setiawan dan Andoko, 2006). 
Peningkatan produktivitas baik kualitas yang harus diperhatikan diantaranya yaitu syarat tumbuh tanaman, pemeliharan bahan tanaman, dan pemeliharaan atau eksploitasi yang cocok dengan kondisi tanaman. Jika terpenuhi faktor-faktor tersebut, usaha peningkatan produksi karet dapat berhasil. Usaha yang dilakukan untuk mendorong pertumbuhan dan perkembangan tanaman antara lain adalah dengan melakukan pemupukan dalam mendorong hal ini pupuk yang diberikan untuk memenuhi nutrisi pada pertumbuhan vegetatif tanaman karet adalah pupuk Abu Janjang Kelapa Sawit dimana dapat memberikan unsur hara seperti: N 18,48\%, P 20 \%, K 3,51\% Mg 2,40\% Ca 1,95\%, berdasarkan kandungan unsur hara K pemberian 325 kg/ha abu janjang setara dengan pemberian 100 kg/ha pupuk KCl. Fungsi Abu Janjang Kelapa Sawit pada tanah akan mempengaruhi sifat kimia kesuburan tanah, perubahan sifat kimia kesuburan tanah ini dapat meningkatkan pertumbuhan karet okulasi (Imron Rosyadi, 2009).

Selain itu digunakan juga Pupuk Organik Jago Tani yang mempunyai perkembangan pada daun jadi lebar, pada berisi tunas akan bermunculan, bunga akan muncul dari semua pori-pori pohon buah akan padat dan berisi, batang akan mengalami pemekaran sel-sel, akar akan berkembang pesat. Unsur yang terkandung dalam Pupuk Organik Jago Tani seperti unsur makro dan mikro N : 0,011 \%,P : 2,26 \%, K : 72,13 \%, Mg : 0.65 \%, Ca : 6.14 \%, S : 9.09 \%, unsur Mikro,Fe : 1524 ppm, Mn : 38 ppm, Cu : 340 ppm, Zn : 86 ppm, B : 51 ppm, Co : 15 ppm (Anonimus, 2011).

\section{BAHAN DAN METODE}

Penelitian ini dilaksanakan di lahan praktek budidaya Fakultas Pertanian Universitas Muhammadiyah Tapanuli Selatan Kota Padangsidimpuan. Penelitian dimulai pada bulan Februari 2017 sampai dengan bulan Juli 2017.

\section{METODE PENELITIAN}

Metode yang digunakan dalam penelitian ini yaitu metode Rancangan Acak Kelompok (RAK) dalam bentuk faktorial, faktor pertama adalah pemberian Abu Janjang Kelapa Sawit (A) dengan 4 level yaitu $A_{0}$ (0 gr/polybag), $A_{1}$ (25 gr/polybag), $A_{2}$ (50 gr/polybag), dan $A_{3}$ (75 
gr/polybag). Sedangkan faktor ke dua adalah pemberian pupuk Organik Jago Tani (J) dengan 4 level yaitu $\mathrm{J}_{0}$ (0 cc/liter air), $\mathrm{J}_{1}$ (2 cc/liter air), $\mathrm{J}_{2}$ (4 cc/liter air), dan $\mathrm{J}_{3}$ (6 cc/liter air). Model yang digunakan dalam rancangan ini adalah model linier (Ali Hanafiah 2010). Model linier ini adalah sebagai berikut :

$$
Y i j k=\mu+\rho i+\alpha j+\beta k+(\alpha \beta) j k+\Sigma i j k
$$

Yijk : Hasil pengamatan faktor A pada taraf ke-j dan faktor J pada taraf ke-k dalam ulangan ke-I

$\mu \quad$ : Efek dari nilai tengah

рi : : Efek dari blok pada taraf ke-I

$\alpha \mathrm{j} \quad$ : Efek dari faktor A pada taraf ke-j

$\quad$ k $\quad$ : Efek dari faktor J pada taraf ke-k

$(\alpha \beta) \mathrm{j}$ : Efek dari interaksi faktor A pada taraf ke-j dan faktor J pada taraf ke-k

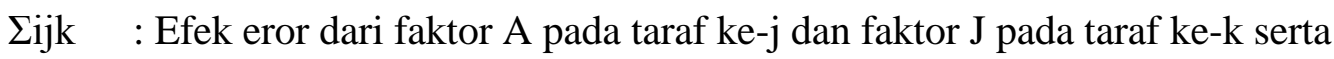
dalam ulangan ke-I

\section{PELAKSANAAN PENELITIAN}

\section{Persiapan Areal}

Tanah lokasi penelitian dibabat dan dibersihkan dari sisa-sisa gulma, akar-akar tanaman dan kotoran lainnya, kemudian tanah tersebut diratakan, dengan cangkul dan dibuat drainase yang baik untuk mencegah penggenangan air sekeliling areal penelitian (pembibitan). Setelah areal dibersihkan maka dibuat plot-plot perlakuan dengan ukuran plot $1 \mathrm{~m}$ x $1 \mathrm{~m}$ dengan arah utara dan selatan. Abu Janjang Kelapa Sawit diberikan pada saat pengisian tanah top soil ke polybag. Pemberian Abu Janjang dilakukan sesuai dengan masing-masing perlakuan.

\section{Pemeliharaan}

Penyiraman dilakukan 2 kali sehari, yaitu pagi dan sore hari kecuali hujan turun. Penyiangan dilakukan sesuai dengan pertumbuhan gulma baik pada areal pembibitan maupun dalam 
polybag. Pupuk Organik Jago Tani diberikan sesuai dengan perlakuan masing-masing. Pengaplikasiannya dilakukan 2 kali yaitu pada umur 2 minggu setelah tanam dan 7 minggu setelah tanam. Pengendalian hama dilakukan secara manual dan kimia, untuk pengendalian secara manual agar hama yang menyerang tanaman dapat dimusnahkan sedangkan cara kimia adalah mengendalikan hama digunakan Curacron 500 EC dengan dosis $2 \mathrm{ml} / 10$ liter, sedangkan untuk penyakit digunakan Antracol dengan dosis 5 g/liter. Penyemprotan dilakukan apabila ada gejala serangan hama maupun penyakit yang menyerang tanaman. Pengaplikasian fungisida dan pestisida dapat dilakukan pada pagi hari dengan cara mencampurnya dengan dosis yang sudah ada. Kemudian disemprotkan merata keseluruh tanaman. Variabel Pengamatan Tinggi tanaman, diameter batang, jumlah tangkai daun, luas daun.

\section{HASIL}

Berdasarkan hasil analisis statistik terhadap variabel pengamatan tinggi tanaman, diameter batang, jumlah tangkai daun, dan luas daun dapat dilihat pada Tabel

Tabel 1: Pengaruh Pemberian Abu Janjang Kelapa Sawit dan Pupuk Organik Jago Tani Terhadap Parameter Tinggi Tanaman (cm)

\begin{tabular}{cccccc}
\hline Perlakuan & $\mathrm{A}_{0}$ & $\mathrm{~A}_{1}$ & $\mathrm{~A}_{2}$ & $\mathrm{~A}_{3}$ & Rataan \\
\hline $\mathrm{J}_{0}$ & $68.663 \mathrm{a}$ & $73.773 \mathrm{a}$ & $71.997 \mathrm{a}$ & $66.773 \mathrm{a}$ & 70.3015 \\
\hline $\mathrm{J}_{1}$ & $74.777 \mathrm{a}$ & $72.330 \mathrm{a}$ & $75.773 \mathrm{a}$ & $64.110 \mathrm{a}$ & 71.7475 \\
\hline $\mathrm{J}_{2}$ & $64.110 \mathrm{a}$ & $74.663 \mathrm{a}$ & $75.217 \mathrm{a}$ & $70.217 \mathrm{a}$ & 71.0517 \\
\hline $\mathrm{J}_{3}$ & $66.220 \mathrm{a}$ & $77.994 \mathrm{a}$ & $76.217 \mathrm{a}$ & $73.320 \mathrm{a}$ & 73.4385 \\
\hline Rataan & 68.4422 & 74.690 & 74.801 & 68.605 & \\
\hline
\end{tabular}

Keterangan : Angka yang diikuti huruf yang sama pada kolom dan baris menunjukkan tidak berbeda nyata menurut Uji DMRT 5 \%. 
Tabel 2 : Pengaruh Pemberian Abu Janjang Kelapa Sawit Dan Pupuk Organik Jago Tani Terhadap Diameter Batang (mm)

\begin{tabular}{cccccc}
\hline Perlakuan & $\mathrm{A}_{0}$ & $\mathrm{~A}_{1}$ & $\mathrm{~A}_{2}$ & $\mathrm{~A}_{3}$ & Rataan \\
\hline $\mathrm{J}_{0}$ & $1,23000 \mathrm{a}$ & $1.24333 \mathrm{a}$ & $1.25000 \mathrm{a}$ & $1.29667 \mathrm{a}$ & 1.255 \\
\hline $\mathrm{J}_{1}$ & $1.27333 \mathrm{a}$ & $1.17667 \mathrm{a}$ & $1.23000 \mathrm{a}$ & $1.29667 \mathrm{a}$ & 1.244 \\
\hline $\mathrm{J}_{2}$ & $1.30000 \mathrm{a}$ & $1.20000 \mathrm{a}$ & $1.19667 \mathrm{a}$ & $1.26333 \mathrm{a}$ & 1.24 \\
\hline $\mathrm{J}_{3}$ & $1.24000 \mathrm{a}$ & $1.22000 \mathrm{a}$ & $1.26333 \mathrm{a}$ & $1.26667 \mathrm{a}$ & 1.247 \\
\hline Rataan & 1.2608 & 1.2099 & 1.235 & 1.280 &
\end{tabular}

Keterangan: Angka yang diikuti dengan huruf yang sama pada baris dan kolom yang sama tidak menunjukkan berbeda nyata menurut uji DMRT pada taraf 5 \%

Tabel 3 : Pengaruh Pemberian Abu Janjang Kelapa Sawit Dan Pupuk Organik Jago Tani Terhadap Parameter Jumlah Tangkai.

\begin{tabular}{cccccc}
\hline Perlakuan & $\mathrm{A}_{0}$ & $\mathrm{~A}_{1}$ & $\mathrm{~A}_{2}$ & $\mathrm{~A}_{3}$ & Rataan \\
\hline $\mathrm{J}_{0}$ & $22.220 \mathrm{a}$ & $21.107 \mathrm{a}$ & $21.887 \mathrm{a}$ & $20.777 \mathrm{a}$ & 21.497 \\
\hline $\mathrm{J}_{1}$ & $21.107 \mathrm{a}$ & $21.220 \mathrm{a}$ & $22.553 \mathrm{a}$ & $20.220 \mathrm{a}$ & 21.275 \\
\hline $\mathrm{J}_{2}$ & $21.107 \mathrm{a}$ & $20.663 \mathrm{a}$ & $22.107 \mathrm{a}$ & $19.773 \mathrm{a}$ & 20.912 \\
\hline $\mathrm{J}_{3}$ & $21.667 \mathrm{a}$ & $22.107 \mathrm{a}$ & $23,440 \mathrm{a}$ & $21.997 \mathrm{a}$ & 22.302 \\
\hline Rataan & 21.525 & 21.274 & 22.496 & 20.691 & \\
\hline
\end{tabular}

Keterangan : Angka yang diikuti dengan huruf yang sama pada baris dan kolom yang sama tidak menunjukkan berbeda nyata menurut uji DMRT pada taraf $5 \%$.

Tabel 4 : Pengaruh Pemberian Abu Janjang Kelapa Sawit Dan Pupuk Organik Jago Tani Terhadap Parameter Luas Daun.

\begin{tabular}{cccccc}
\hline Perlakuan & $\mathrm{A}_{0}$ & $\mathrm{~A}_{1}$ & $\mathrm{~A}_{2}$ & $\mathrm{~A}_{3}$ & Rataan \\
\hline $\mathrm{J}_{0}$ & $91.710 \mathrm{a}$ & $93.470 \mathrm{a}$ & $101.717 \mathrm{a}$ & $92.963 \mathrm{a}$ & 71.7242 \\
\hline $\mathrm{J}_{1}$ & $94.770 \mathrm{a}$ & $91.297 \mathrm{a}$ & $99.940 \mathrm{a}$ & $91.070 \mathrm{a}$ & 95.2692 \\
\hline $\mathrm{J}_{2}$ & $95.813 \mathrm{a}$ & $93.510 \mathrm{a}$ & $86.740 \mathrm{a}$ & $94.820 \mathrm{a}$ & 92.7207 \\
\hline $\mathrm{J}_{3}$ & $93.727 \mathrm{a}$ & $92.570 \mathrm{a}$ & $87.390 \mathrm{a}$ & $98.283 \mathrm{a}$ & 68.4217 \\
\hline Rataan & 94.005 & 92.7117 & 93.9467 & 94.284 & \\
\hline
\end{tabular}

Keterangan : Angka yang diikuti dengan huruf yang sama pada baris dan kolom yang sama menunjukkan tidak berbeda nyata menurut uji DMRT pada taraf $5 \%$. 
Berdasarkan Tabel 1, Tabel 2, Tabel 3, dan Tabel 4, diperoleh bahwa perlakuan pemberian Abu Janjang Kelapa Sawit memberikan pengaruh yang nyata pada pengamatan tinggi tanaman. Sedangkan pengaruh yang tidak nyata dijumpai pada pengamatan diameter batang, pengamatan jumlah tangkai, pengamatan luas daun. Sedangkan pemberian pupuk organik Jago Tani tidak memberikan pengaruh yang nyata pada pengamatan tinggi tanaman, diameter batang, jumlah tangkai, dan luas daun.

Pengaruh yang nyata pada perlakuan Abu Janjang Kelapa Sawit pada pengamatan tinggi tanaman dipengaruhi oleh sifat dari Abu Janjang Kelapa Sawit tersebut bahwa Abu Janjang Kelapa Sawit yang merupakan hasil pembakaran tandan kosong kelapa sawit yang memiliki kandungan unsur hara yang dapat membantu peroses metabolisme tanaman sehingga membantu pembentukan batang dan daun menggemburkan tanah, menghidupkan kembali unsur hara yang terikat dalam tanah.

Hal ini sesuai dengan pendapat Roma Asi, (2002) yang mengatakan bahwa Pemberian pupuk kepada tanaman tidak lain adalah bertujuan untuk memenuhi kebutuhan hara tanaman sehingga tanaman tumbuh subur dan produksi tinggi. Tindakan pemupukan ini merupakan salah satu usaha yang dapat dilakukan untuk memperoleh pertumbuhan tanaman yang baik serta produksi yang maksimum. Pengaruh yang tidak nyata pada pengamatan tinggi tanaman, diameter batang, jumlah tangkai, luas daun disebabkan oleh rendahnya unsur $\mathrm{N}$ yang dikandung oleh Pupuk Organik Jago Tani. Adanya organik pembatas yaitu berapa tinggi dosis yang diberikan tidak mampu memberikan pengaruh yang berbeda terhadap berapa dosis yang ditentukan sehingga dosis yang tinggi tidak berpengaruh nyata pada tanaman karena tanaman hanya mengambil unsur yang dibutuhkan oleh tanaman tersebut (Dartius, 1956). Dan kemungkinan lainnya disebabkan oleh faktor genetik atau lingkungan dimana faktor lingkungan salah satunya adalah suhu yang kurang baik pada saat penelitian. 


\section{KESIMPULAN}

Berdasaran hasil penelitian yang dilakukan dapat disimpulkan bahwa pemberian Abu Janjang

Kelapa Sawit memberikan pengaruh yang nyata terhadap pertumbuhan vegetatif tanaman Karet, sedangkan pemberian pupuk organik Jago Tani tidak memberikan pengaruh yang nyata terhadap pertumbuhan vegetatif tanaman Karet.

\section{SARAN}

Berdasaran hasil penelitian yang dilakukan disarankan untuk memberikan Abu Janjang Kelapa Sawit pada media tanam pembibitan tanaman Karet.

\section{DAFTAR PUSTAKA}

Anomimus,2011. Pupuk Organik Jago Tani. Product by :Mutiara Kraton Jimmy Hantu dan Co.Trans Bisnis Indonesia Bogor-Indonesia.

, 2005. Bahan Tanaman Karet Untuk Peremajaan Karet Rakyat. Departemen Pertanian Direktorat Jendral Pertanian.

Anonimos,2011. (dalam) www.pupukjagotani.blogspot.com.

Anonimous, 2008, Brosur Pupuk Organik Cair Bintang Kuda Laut. PT. Pertani (Persero)

Anonimus 2008. Panduan Lengkap Karet. Penebar Swadaya. Jakarta.

Anonimus, 2011. Pemamfaatan Limbah Janjang Kosong Kelapa Sawit Menjadi

Anonimus, http://bppkedungwaru.blosgpot.com/2013/01/Fungsi Unsur Hara Bagi Tanaman

Anonimus,2011.(dalam) http://www.icracf.org,disbun.com

Anwar, C. 2006. Manajemen dan Teknologi Budidaya Karet. Makalah pelatihan "Tekno Ekonomi Agribisnis Karet” . 18 Mei 2006. Jakarta.

Aryantoro Hadi Ir.2006. Budi Daya Tanaman Perkebunan.

Dartius,MS.Ir,1996.Fisiologi Tanaman

Dartius.Ir.MS.1996. Fisiologi Tanaman, Fakultas Pertanian USU, MEDAN

Dwidjoseputro. D. 2000. Pengantar Fisiologi Tumbuhan. Gramedia Utama. Jakarta.

Gomez. K. A,and A. A. Gomez. 1996. Prosedur Statistik Untuk penelitian Pertanian, penerjemah Endang Sayamsudin dan Justika Baharsyah UI-Press, Jakarta. 
Hanafiah,A Kemas.Ir Dr 2010.Rancangan Percobaan.

Hardjodinomo, 2009, Ilmu Memupuk, Bandung Bina Cipta

Imron Rosyadi, 2009. Perpustakaan Departemen Biologi. Insitut Pertanian Bogor. Bogor.

Lasminingsih Mudji, MS \& Hendra H. Sipayung, SP, MM, 2012, Petunjuk Praktis Pembibitan Karet. AgroMedia, Jakarta

Lubis. Dkk. 1991. Buletin Vol. V. No.3. Bagian Penelitian PT. Perkebunan IX. Medan.

Marsono dan P. Sigit, 2001, Pupuk Akar, Daun Jenis dan Aplikasi. PT. Penebar Swadaya, Jakarta

Novizan, 2001. Petunjuk Pemupukan Efektif, Agromedia Pustaka, Jakarta

Pinus dan Marsono. 2000, Petunjuk Penggunaan Pupuk, Penerbit PT. Penebar Swadaya, Jakarta.

Setiawan, Didit Heru, Andoko Agus, 2008. Petunjuk Lengkap Budidaya Karet. Agromedia Pustaka, Jakarta

Setiawan, H. D.Ir, dan Handoko,A.Drs.2006.Petunjuk Lengkap Budidaya Karet.

Settamidjaja, 2003. Karet Budidaya dan pengolahannya, Penerbit Kamisius, Yokyakarta.

Setyamidjaja Djoehana,2012.Seni Budidaya Karet.

Sianturi, H. S. D. 2007. Budidaya Karet.USU Press.Medan.(dalam) http://repositori.USU .ac.id

Sianturi, H. S. D., 2001. Budidaya Tanaman Karet. USU Press, Medan.

Sitompul Dan Guritno.1995 Fisiologi Tumbuhan. Rajawali Pers. Jakarta.

Soepardi, G. 1983. Sifat dan Ciri Tanah. Jurusan Ilmu Tanah, Fakultas Pertanian,

Soepardi. G. 2003. Sifat dan Ciri Tanah. Departemen Ilmu Tanah. Fakultas Pertanian IPB. Bogor.

Sutedjo, 2004, Pengantar Bercocok Tanam Kelapa Sawit Fakultas Pertanian USU Medan,

Syakir M, 2010, Budidaya dan Pasca Panen Karet, Pusat Penelitian dan Pengembangan Perkebunan.

Tim Penulis Ps.20012. Panduan Lengkap Karet.Ppenebar Swadaya. IKPI. 